\title{
Impact of the Antiphospholipid Syndrome on Complications during Pregnancy
}

\author{
Ekkehard Schleussner \\ Abteilung Geburtshilfe, Klinik für Frauenheilkunde und Geburtshilfe, Klinikum der Friedrich Schiller Universität, Jena, Germany
}

\section{Key Words}

Antiphospholipid syndrome · Pregnancy outcome · Thrombosis . Fetal loss · Low-molecular-weight heparin · Low-dose aspirin

\section{Summary}

The antiphospholipid syndrome (APS) is an autoimmune disease characterized by the appearance of antiphospholipid antibodies (APA) and at least one clinical manifestation like venous and arterial thrombosis or recurrent miscarriages and fetal loss in the second and third trimester. This most common acquired thrombophilia can also cause placental insufficiency, preeclampsia, intrauterine growth retardation, and placental abruption. Several potential pathogenic pathways leading to a procoagulant state by activation of endothelial cells, monocytes or platelets and inhibition of the protein $\mathrm{C}$ activation pathway have been identified. These are supposed to be responsible for thrombosis and obstetric complications. Failed trophoblast differentiation and invasiveness, with subsequently hampered uteroplacental development, as well as thrombosis in the placental vessels are further pathogenic pathways for observed complications specific for pregnancy. Tests for anticardiolipin antibodies and lupus anticoagulant are most commonly used in clinical practice although antiphospholipid antibodies are a heterogeneous group. Current criteria for the classification of APS recommend the use of standardized ELISAs that measure $\beta 2$ glycoprotein I-dependent IgG and IgM anticardiolipin antibodies and/or lupus anticoagulant. Current recommendations regarding prophylactic and therapeutic strategies in pregnancy are based on a systematic Cochrane review. Although APS is an autoimmune disease, anticoagulant therapy is the favored strategy to prevent thromboembolic events, miscarriages, or other pregnancy complications. The recommended therapy is the combination of heparin and low-dose aspirin reducing pregnancy loss by $54 \%$. Aspirin alone, prednisone, or intravenous immunoglobulin infusion had no significant beneficial effect on pregnancy outcome, but rather a higher rate of side effects. Oral anticoagulants are contraindicated during pregnancy because of substantial embryotoxic side effects. Currently lowmolecular-weight heparin replaces unfractionated heparin as drug of choice because of safe use for mother and fetus as well as fewer side effects as several studies have shown. Our experience has taught us that prophylaxis should be initiated as soon as pregnancy has been recognized in order to prevent the described pathologies in placental development.

\section{Schlüsselwörter}

Antiphospholipid-Antikörpersyndrom · Schwangerschaft . Fehlgeburt - Thrombose - Niedermolekuleres Heparin . Niedrig dosiertes Aspirin

\section{Zusammenfassung}

Das Antiphospholipid-Antikörpersyndrom (APS) ist eine Autoimmunerkrankung, die durch den Nachweis von Antiphospholipid-Antikörpern (APA) und mindestens einem klinischem Symptom wie eine arterielle und venöse Thrombose, wiederholte Fehlgeburten oder Spätaborte charakterisiert wird. Durch diese häufigste erworbene Thrombophilie können auch eine Plazentainsuffizienz, Präeklampsie, fetale intrauterine Wachstumsretardierung oder vorzeitige Plazentalösung hervorgerufen werden. In der Pathogenese dieses prokoagulatorischen Zustands spielen die Aktivierung des Endothels, von Monozyten und Thrombozyten sowie eine Hemmung der Protein-C-Aktivität eine Rolle, die für die Entstehung einer Thrombose und von Schwangerschaftskomplikationen verantwortlich gemacht werden. Die Störung der Throphoblastdifferenzierung und -invasion mit dadurch hervorgerufener Beeinträchtigung der uteroplazentaren Entwicklung sowie Mikrothrombosen im plazentaren Stromgebiet sind weitere Ursachen der auftretenden Schwangerschaftskomplikationen. In der klinischen Diagnostik werden meist Lupuskoagulanz und Anticardiolipin-Antikörper bestimmt, obwohl die APA eine heterogene Gruppe darstellen. Die aktuellen Kriterien zur APS-Klassifikation setzen eine standardisierte Messung von $\beta 2$-Glykoprotein-I-abhängigen IgG- und IgM-Anticardiolipin-Antikörpern mittels ELISA und/oder des Lupuskoagulanztests voraus. Die Empfehlungen zu Prophylaxe und Therapie in der Schwangerschaft beruhen auf einer Cochrane-Meta-Analyse. Obwohl das APS eine Autoimmunerkrankung ist, wird eine antikoagulatorische Therapie zur Verhinderung von Thrombosen, Fehlgeburten und Schwangerschaftskomplikationen empfohlen. Eine Kombination von Heparin mit niedrig dosiertem Aspirin kann die Rate an Schwangerschaftsverlusten um 54\% senken. Alleiniges Aspirin, Prednisolon oder i.v. Immunglobulininfusion haben keinen günstigen Effekt auf den Schwangerschaftserfolg, jedoch eine höhere Nebenwirkungsrate. Eine orale Antikoagulation ist auf Grund embryotoxischer Nebenwirkungen kontraindiziert. Als Medikation der Wahl setzen sich derzeit niedermolekulare Heparine durch, da sie weniger Nebenwirkungen bei gleicher Sicherheit für Mutter und Fetus als unfraktioniertes Heparin aufweisen. Eigene Erfahrungen lassen uns zu einem möglichst frühen Beginn der Prophylaxe in der Schwangerschaft raten, um die beschriebenen plazentaren Entwicklungsstörungen zu vermeiden.

\begin{tabular}{|c|c|}
\hline KARGER & (c) 2006 S. Karger GmbH, Freiburg \\
\hline $\begin{array}{l}\text { Fax +4976145207 } 14 \\
\text { E-mail Information@Karger.de } \\
\text { www.karger.com }\end{array}$ & $\begin{array}{l}\text { Accessible online at: } \\
\text { www.karger.com/tmh }\end{array}$ \\
\hline
\end{tabular}

Prof. Dr. med. Ekkehard Schleussner

Abteilung Geburtshilfe, Klinik für Frauenheilkunde und Geburtshilfe

Klinikum der Friedrich Schiller Universität

Bachstraße 18, 07740 Jena, Germany

Tel. +49 3641 9332-30, Fax -86

E-mail ekkehard.schleussner@med.uni-jena.de 


\section{Introduction}

The antiphospholipid syndrome (APS) is an autoimmune disease characterized by antiphospholipid antibodies (APA) along with at least one clinical manifestation [1]. The most specific clinical features are thrombosis (both venous and arterial), recurrent miscarriages and fetal loss in the second and third trimester, and autoimmune thrombocytopenia. It is the most common acquired thrombophilia and was originally described as part of systemic lupus erythematosus (SLE). Therefore APS is considered to be primary when its occurrence is isolated, but secondary when associated with a connective tissue disease, particularly SLE [2].

Recent findings demonstrate the growing importance of APS for obstetricians pertaining the role of this autoimmune disease in recurrent pregnancy loss, placental insufficiency, preeclampsia, placental abruption, and thrombosis.

\section{Classification and Diagnosis}

Criteria for the classification of patients with definite APS were developed during a consensus meeting in Sapporo in 1998 [3] (table 1). Sapporo criteria have been evaluated and reported to have a sensitivity of $71 \%$ and a specificity of $98 \%$, suggesting that the threshold for inclusion is high and that most cases have 'definite' APS [4].

Thus, in clinical practice APA should be monitored in all patients with venous or arterial thrombosis and fetal loss for which there is no alternative explanation, particularly in the presence of recurrent manifestations. Likewise, unexplained thrombocytopenia, hemolytic anemia and prolongation of any phospholipid coagulation tests should lead to determination of APA status because they could also represent clinical features of the APS (table 2).

APA tests may also result positive in a variety of other disorders, including connective tissue diseases, infectious disorders such as syphilis, Q fever, and AIDS. In these conditions, IgM isotype is present predominantly in low titers and not usually associated with clinical features of APS [5].

APA are a heterogeneous group of autoantibodies that are detected by immunoassays and functional coagulation tests. Tests for anticardiolipin antibodies and lupus anticoagulant are most commonly used in clinical practice. However, it is demonstrated that one of the main target antigens of APA actually consists of $\beta 2$-glycoprotein I ( $\beta 2-\mathrm{GPI})$, a phospholipidbinding protein involved in coagulation processes. Also antibodies directed toward other coagulation proteins, e.g. prothrombin, protein $\mathrm{S}$, protein $\mathrm{C}$ and annexin $\mathrm{V}$, act as phospholipid cofactors [6]. Even tough not yet fully understood, it is generally believed that not phospholipids but rather phospholipid-binding proteins or phospholipid-protein complexes constitute the real target of APA [7]. It has yet to be evaluated whether or not specific testing of these autoantibodies add sig- nificantly in the APS diagnosis [8]. Current criteria for the classification of APS recommend the use of standardized ELISAs that measure ( $\beta 2-$ GPI-dependent IgG and IgM anticardiolipin antibodies and/or lupus anticoagulant according to the recommended criteria from the International Society on Thrombosis and Haemostasis Subcommittee on Lupus Anticoagulant/Antiphospholipid Antibody (see table 1) [9].

\section{Epidemiology}

A high variability in the prevalence of APA is reported in the normal population. Several studies have reported a frequency of $1-5 \%$ in the normal controls of case control studies [10]. The prevalence increases with age up to $12 \%$ in elderly people with chronic diseases [11]. A secondary APS will be developed in $30 \%$ of SLE patients [10]. In patients with rheumatoid arthritis a mean prevalence of $28 \%$ was reported [12].

Venous thrombosis can affect the vessels of any organ and is the most common manifestation of APS, followed by cerebral ischemia in the form of strokes and transient ischemic attacks [5]. Particularly, deep vein thrombosis of the lower limb occurs in up to $55 \%$, half of whom also have pulmonary emboli [13]. The absolute risk of developing new thrombosis is low $(<1 \%$ per year) in otherwise healthy patients without prior thrombotic events, may be moderately increased (up to $10 \%$ per year) in women with recurrent fetal loss without prior thrombosis, and is highest $(>10 \%$ in the first year) in patients with a history of venous thrombosis who have discontinued anticoagulant drugs within 6 months [14].

Prospective studies in the general population have shown that the occurrence of APA was predictive of both a first deep venous thrombosis [15] and recurrent thromboembolism [16]. The prevalence of APA is about $30 \%$ in patients with venous thrombosis [10]. Two thirds of puerperal cerebral sinus venous thromboses seem to be associated with positive APA [17].

Among 128 unselected patients with primary APS, the clinical manifestations were deep vein thrombosis in $62(48 \%)$ patients, arterial thrombosis in $63(49 \%)$ patients, miscarriage in $177 / 320(55 \%)$ pregnancies, and pulmonary embolism in $37(30 \%)$ patients. Other clinical manifestations were migraine in $51(40 \%)$, thrombocytopenia in $48(38 \%)$, livedo reticularis in 47 (37\%), and valvular disease in 27 (21\%) patients [18].

The prevalence of anticardiolipin antibodies in general obstetric clinics has been reported to be between 2.7 and $7 \%$. Prospective studies of low-risk pregnancies have found that their presence carried a 3-9 times higher risk of fetal loss [19]. A positive test for APA may be found in up to $45 \%$ of women with recurrent pregnancy loss [20]. An APS was present with either recurrent embryonic loss [21] or late abortion after 10 weeks of gestation (fig. 1) [22]. It is found in $10-15 \%$ of women with fetal death in later pregnancy [23]. In women with a history of at least three prior miscarriages and no ab- 
Table 1. Criteria for the classification of definite APS [3] ${ }^{\mathrm{a}}$

Clinical criteria

1) Vascular thrombosis

One or more clinical episodes of arterial, venous or small-vessel thrombosis in any tissue or organ. Thrombosis must be confirmed by imaging or Doppler studies or histopathology, with the exception of superficial venous thrombosis. For histopathologic confirmation, thrombosis should be present without significant inflammation in the vessel wall.

2) Pregnancy morbidity

a) One or more unexplained deaths of a morphologically normal fetus at or beyond the 10th week of gestation, with normal fetal morphology documented by ultrasonography or by direct examination of the fetus, or

b) One or more premature births of a morphologically normal neonate at or before the 34th week of gestation because of severe preeclampsia or eclampsia, or severe placental insufficiency, or

c) Three or more unexplained consecutive spontaneous abortions before the 10th week of gestation, with maternal anatomic or hormonal abnormalities and paternal and maternal chromosomal causes excluded.

In studies of populations of patients who have more than 1 type of pregnancy morbidity, investigators are strongly encouraged to stratify groups of subjects according to $\mathrm{a}, \mathrm{b}$ or $\mathrm{c}$ above.

Laboratory criteria

1) Anticardiolipin antibody of IgG and/or IgM isotype in blood, present in medium or high titer, on 2 or more occasions, at least 6 weeks apart, measured by a standardized enzyme-linked immunosorbent assay for $\beta 2$-GPI-dependent anticardiolipin antibodies.

2) Lupus anticoagulant present in plasma, on 2 or more occasions at least 6 weeks apart, detected according to the guidelines of the International Society of Thrombosis and Hemostasis (Scientific Subcommittee on Lupus Anticoagulants/Phospholipid-Dependent Antibodies) in the following steps:

a) Prolonged phospholipid-dependent coagulation demonstrated on a screening test, e.g., activated partial thromboplastin time, kaolin clotting time, dilute Russell's viper venom time, dilute prothrombin time, textarin time.

b) Failure to correct the prolonged coagulation time on the screening test by mixing with normal platelet-poor plasma.

c) Shortening or correction of the prolonged coagulation time on the screening test by addition of excess phospholipid.

d) Exclusion of other coagulopathies, e.g., factor VIII inhibitor or heparin, as appropriate.

aDefinite APS is considered to be present if at least 1 of the clinical criteria and 1 of the laboratory criteria are met.

Table 2. Common clinical features to APS

Arterial or venous thrombosis, also atypical forms

Recurrent early pregnancy loss

Late pregnancy loss or stillbirth

Preeclampsia, eclampsia or HELLP syndrome

Fetal intrauterine growth restriction

Placental abruption

Thrombocytopenia

Hemolytic anemia

Cardiac valve disease

Transient cerebral ischemia

Livedo reticularis

normality, $90 \%$ miscarried and $94 \%$ experience fetal losses in further pregnancy [21].

The relation between APS and preeclampsia has been demonstrated in several studies (fig. 1) [24]. In a series of more than 300 patients with severe preeclampsia an overall incidence of $21 \%$ was found related to detectable APA, with a $27 \%$ incidence in the group with delivery at less than 28 weeks of gestation [25]. It should be noted that most studies found only an association with early-onset severe preeclampsia [26].

Women with APS are also at a substantial risk for intrauterine growth retardation at around 30\% [26]. Based on data from
Yasuda et al. [27], the risk increased nearly 7-fold (odds ratio 6.91; 95\%-CI 2.70-17.68)

\section{Pathogenesis}

Several potential pathogenic pathways have been identified which are considered responsible for thrombosis and obstetric complications in patients with APS (fig. 2). Various studies have suggested that APA might cause thrombosis by activation of endothelial cells, monocytes or platelets, or by inhibition of the protein $\mathrm{C}$ activation pathway [5]. APA interfere with the function of the coagulation cascade, leading to a procoagulant state. Most of the antigenic targets of APA (table 3) are involved in the initiation and control of coagulation, thus influencing the pro- and anticoagulant balance [28]. Examples include inhibition of the activated protein $\mathrm{C}$ and antithrombin III pathways, inhibition of fibrinolysis, and upregulation of tissue factor activity. [13].

In this respect it may play a central role that the anticoagulant function of $\beta 2$-GPI is compromised by APA. APA bind to the endothelial cell surface in a $\beta 2$-GPI-dependent manner leading to direct endothelial cell activation, which is distinguished by upregulation of cell surface adhesion molecules and in- 


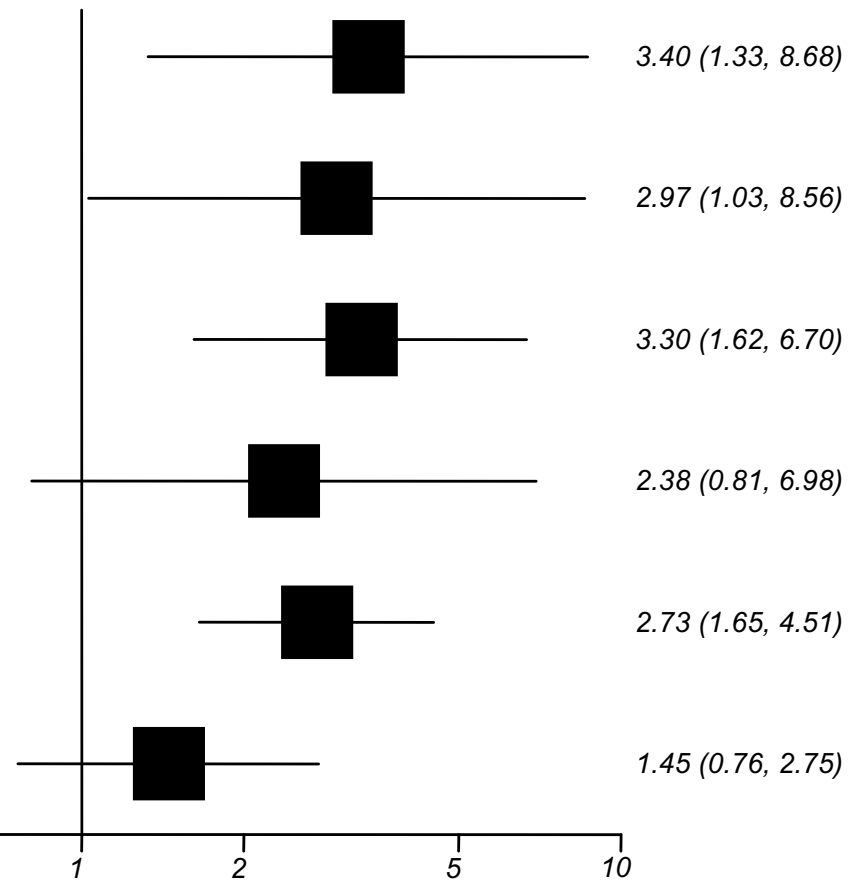

Fig. 1. Risk of early and late fetal loss in woman with APS. The square represent the overall average odds ratio and the confidence interval from pooling all the studies together (modified from the meta-analysis of Robertson et al. 2005 [24])
APA and late loss

Lupus anticoagulants and late loss

APA and preeclampsia

Lupus anticoagulants and preeclampsia

Odds ratio $(95 \%-\mathrm{Cl}$ random $)$
Table 3. Antigenic targets of antiphospholipid antibodies [28]

\section{$\beta 2-G P I$}

(Human) Prothrombin

(Activated) Protein C

Protein S

Tissue-type plasminogen activator

Annexin V

Thrombomodulin

Oxidized low-density lipoproteins

Factor XII

High- and low-molecular-weight kininogens

Factor VII/VIIa

Complement components $\mathrm{H}$ and $\mathrm{C} 4 \mathrm{~b}$

Endothelial protein C receptor (EPCR)

creased secretion of IL-6 and prostaglandins [13]. This endothelial dysfunction has recently been demonstrated clinically by an impaired vasodilatory response to increased blood flow shear stress [29]. Since clinical manifestation of APS does not occur in every case, an additional factor such as vascular bed injuries, cytokine and endothelial activation by infection or other procoagulant factors (immobilization, hormone and pregnancy effects, etc.), may be required.

In pregnancy, thrombosis of placental vessels may result in placental insufficiency which can in turn lead to fetal loss. Placental pathology is variable but can include infarction with uteroplacental thrombus, perivillous fibrin deposits, and even chronic inflammatory lesions [30]. Placental tissue demonstrated more infarction, intravascular fibrin deposition, syncy-
Table 4. LMWH suitable during pregnancy

\begin{tabular}{ll}
\hline Drug & (German) Brand name \\
\hline Enoxaparin & Clexane 40 \\
Certoparin & Mono-Embolex \\
Dalteparin & Fragmin P forte 5000 IE \\
Nadroparin & Fraxiparin 0.4 ml \\
Tinzaparin & Innohep 3500 IE \\
\hline
\end{tabular}

tial knot formation, and fibrosis than controls. These non-specific histologic features are not different in tissues from live births and pregnancy losses, or in treated and untreated pregnancies [31].

Annexin- $\mathrm{V}$, an anticoagulant phospholipid-binding protein, is found expressed on the apical membranes of syncytiotrophoblasts as early as 7 weeks of gestation until term. The concentration of this protein appears to be reduced in the presence of APA, which may play an important role in the placental insufficiency and consequent fetal loss [32]. Disruption of this anticoagulant shield may predispose to coagulation in the intervillous space of the placenta and to recurrent spontaneous pregnancy losses.

Interestingly the most frequent histological abnormality in primary, APS-associated, early pregnancy loss is not excessive intervillous thrombosis but a defective decidual endovascular trophoblast invasion [33]. Lupus anticoagulant-positive sera cause increased apoptosis and reduced proliferation of the trophoblast in cultured placental villous tissue [34]. APA has 
Fig. 2. Pathogenic mechanisms in APS (modified from Hanly, J. G, CMAJ 24-Jun-03; 168(13) Page(s) 1675-1682 by permission of the publisher.@ 2003 Canadian Medical Association).

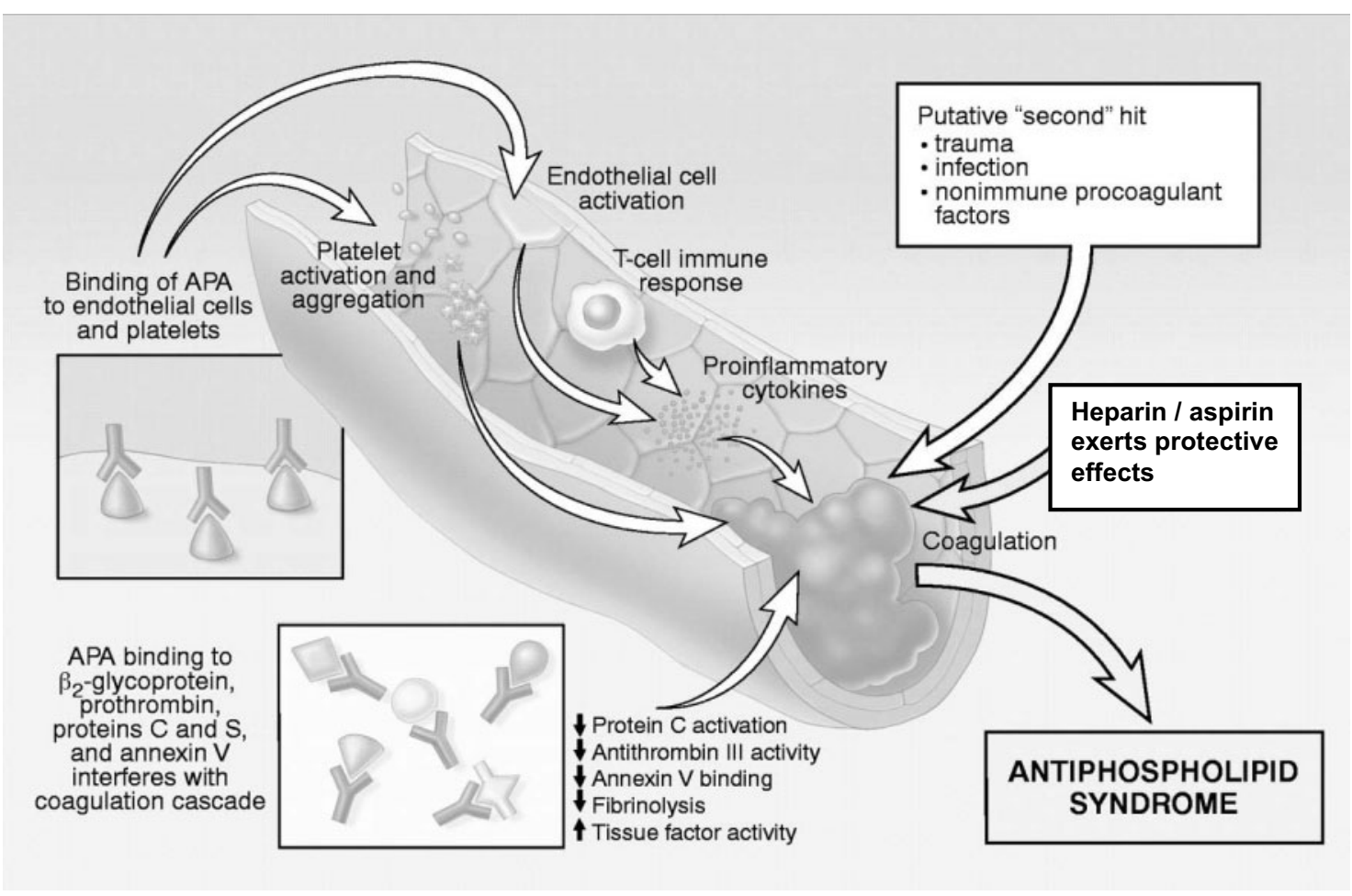

also been found to inhibit the differentiation of the extravillous throphoblast cells in vitro. This leads to the suggestion that this failure of trophoblast differentiation and invasiveness subsequently hampers uteroplacental development und thus represents a further pathogenic pathway for the observed complication during pregnancy [35].

\section{Prophylaxis and Therapy during Pregnancy}

The management of the APS during pregnancy comprises the following objectives:

- primary prophylaxis in asymptomatic pregnant women,

- secondary prophylaxis of recurrences in women who have previously developed a pregnancy complication or thrombosis, and

- treatment of an acute thromboembolic event or complication of the ongoing pregnancy.

Current recommendations regarding prophylactic and therapeutic strategies in pregnancy are based on a systematic review and meta-analysis of randomized controlled trials in the Cochrane database [36]. Within a planned treatment, both efficacy and adverse outcomes must be considered. Thirteen studies, involving 849 participants, were included using treatment with intravenous immunoglobulin infusion, low-dose aspirin, either alone, or in combination with prednisone, unfractionated heparin or low-molecular-weight heparin (LMWH). Women with no history of thrombosis or prior fetal loss who were found to have APA during the first pregnancy do not need any treatment. Women with APS who have had prior pregnancy complications or thromboembolic events, whether or not associated with pregnancy, must receive therapy throughout pregnancy and the post-partum period. Our experience has taught us that prophylaxis should be initiated as soon as pregnancy has been recognized in order to prevent the described pathologies in placental development.

Although APS is an autoimmune disease, anticoagulant therapy is the favored strategy to prevent thromboembolic events, miscarriages, or other pregnancy complications. The recommended therapy is a combination of heparin and low-dose aspirin reducing pregnancy loss by $54 \%$ (relative risk (RR) 0.46 ; $95 \%$ confidence interval (95\%-CI) 0.29-0.71) [36]. Aspirin alone, when compared to placebo or standard care in 3 studies, had no significant beneficial effect on pregnancy outcome (RR 1.05; 95\%-CI 0.66-1.68) [19] (fig. 3).

Oral anticoagulants are contraindicated during pregnancy because of substantial side effects. Coumarin derivatives cross the placenta and are associated with embryopathy in up to $5 \%$ of exposed fetuses, especially during the first trimester. Central nervous system lesions by intracerebral hemorrhages can occur in any trimester [37].

A prednisone plus aspirin therapy in moderate to high doses could also not be recommended due to the lack of a beneficial effect on the risk of fetal loss as compared to placebo or aspirin alone (RR 0.85, 95\%-CI 0.53-1.36). On the other hand, prednisone administration significantly increases the risk for preterm delivery, preeclampsia, low birth weight, gestational diabetes, and neonatal intensive care admission [38].

Intravenous immunoglobulin infusion seems to be effective in some uncontrolled studies, but in randomized studies this very 


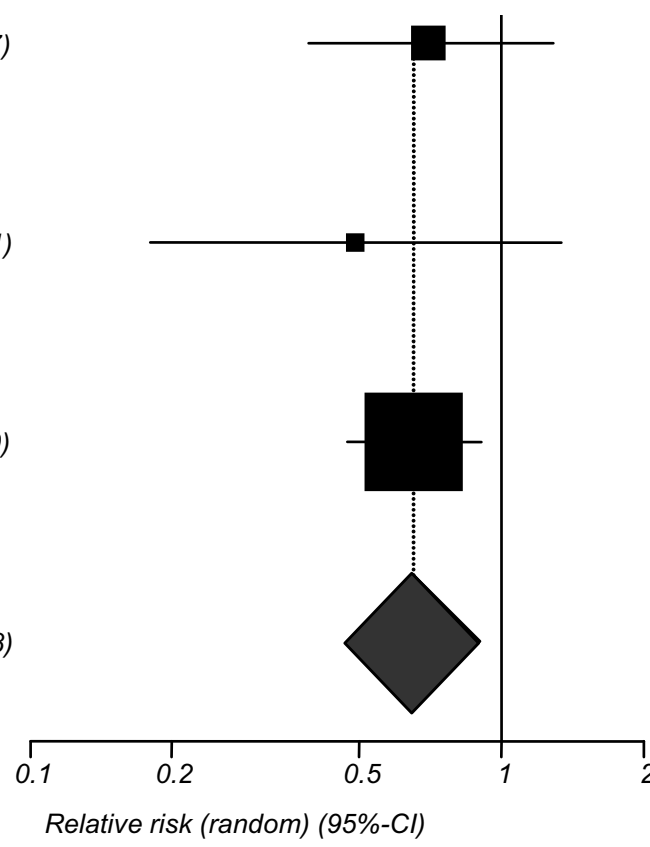

Fig. 3. Adverse pregnancy outcome with therapy of heparin + aspirin compared to other therapy (Chochrane analysis) [36]. IVIG $=$ intravenous immunoglobulin.

expensive therapy was inferior to LMWH combined with aspirin or unfractionated heparin and aspirin alone (pregnancy loss or premature delivery RR 2.5, 95\%-CI 1.27-4.95) [36]. In contrast, outcomes of intravenous immunoglobulin infusion did not significantly differ from that of prednisone and aspirin administration [39].

Although there is only a limited number of randomized studies as yet [40-42], LMWH currently replaces unfractionated heparin as drug of choice. LMWH exhibits a number of advantages [43]:

- LMWH do not cross the placenta and has no teratogenic or fetotoxic risks,

- the use is safe for mother and fetus as shown in several studies,

- improved bioavailability and easy route of self-administration,

- a longer half-life allows mostly only once daily injection,

- no monitoring necessary in prophylactic dosages,

- fewer side effects like hemorrhage, heparin-induced thrombocytopenia or osteoporosis.

The risk for preterm delivery was lower in LMWH-treated pregnancies compared with unfractionated heparin (27 vs. $48 \% ; p<0.001)$, whereas the rate of preeclampsia and intrauterine growth retardation was not different [42].

In own results the combination of LMWH and low-dose aspirin improved the rate of successful pregnancy outcome from
32 to $88 \%$ [44]. Generally all different LMWH used in clinical practice are suitable for prophylaxis during pregnancy (table 4). However, experience has mostly gained only for dalteparin [45], enoxaparin [46], and tinzaparin [47].

Low-dose aspirin prophylaxis with $100 \mathrm{mg}$ daily is usually initiated as early as possible in pregnancy, but should be stopped after 35 weeks of gestation to prevent hemorrhages sub partum. LMWH therapy should be continued up to term, stopped during delivery, but started immediately after birth for at least 4-6 weeks because the highest risk for venous and arterial thrombosis is post partum.

In women with acute venous thromboembolism, adjusteddose LMWH is recommend throughout pregnancy for at least 5 days, followed by adjusted-dose LMWH for the remainder of the pregnancy and at least 6 weeks postpartum [48].

In nonpregnant patients with APS a moderately intense oral anticoagulation (adjusted to a target international normalized ratio of 2.0-3.0) reduces the risk of recurrent venous thrombosis by $80-90 \%$, irrespective of the presence of APA, and may be effective in preventing recurrent arterial thrombosis [14].

The elucidation of the complexity of pathogenic mechanisms during pregnancy allows us today to substantially improve pregnancy outcome and women's health.

Yet many questions remain open and await answers that further experimental research as well as prospective randomized clinical trials may deliver. 


\section{References}

1 Harris EN: Syndrome of the black swan. Br J Rheumatol 1987;26:324-326.

2 Girling J, deSwiet M: Acquired thrombophilia. Baillieres Clin Obstet Gynaecol 1997;11:447-462.

3 Wilson WA, Gharavi AE, Koike T, Lockshin MD, Branch DW, Piette JC, Brey R, Derksen R, Harris EN, Hughes GR, Triplett DA, Khamashta MA: International consensus statement on preliminary classification criteria for definite antiphospholipid syndrome: report of an international workshop. Arthritis Rheum 1999;42:1309-1311.

4 Lockshin MD, Sammaritano LR, Schwartzman S. Validation of the Sapporo criteria for antiphospholipid syndrome. Arthritis Rheum 2000;43:440-443.

5 Bertolaccini ML, Khamashta MA, Hughes G: Diagnosis of antiphospholipid syndrome. Nat Clin Pract Rheumatol 2005;1:40-46.

6 Bertolaccini ML, Khamashta MA: Laboratory diagnosis and management challenges in the antiphospholipid syndrome. Lupus 2006;15:172-178.

7 Bizzarro N, Tonutti E, Villalta D, Tampona M, Bozzoli R: Prevalence and clinical correlation of antiphospholipid-binding protein antibodies in anticardiolipin-negative patients with systemic lupus erythematosus and women with unexplained recurren miscarriages. Arch Pathol Lab Med 2005;129:61-68.

8 Greaves M: Antiphospholipid syndrome: clinical manifestations and management. Thromb Res 2005; 115S:27-30.

9 Greaves M, Cohen H, Machin SJ, Mackie I: Guidelines on the investigation and management of the antiphospholipid syndrome. Br J Haematol 2000; 109:704-715.

10 Petri M: Epidemiology of the antiphospholipid antibody syndrome. J Autoimmun 2000;15:145-151.

11 Juby AG, Davis P: Prevalence and disease associations of certain autoantibodies in elderly patients. Clin Invest Med 1998;21:4-11.

12 Olech E, Merrill JT: The prevalence and clinical significance of antiphospholipid antibodies in rheumatoid arthritis. Curr Rheumatol Rep 2006;8: 100-108.

13 Henly JG: Antiphospholipid syndrome: an overview. CMAJ 2003;168:1675-1682.

14 Lim W, Crowther MA, Eikelboom JW: Management of antiphospholipid antibody syndrome: a systematic review. JAMA 2006;295:1050-1057.

15 Ginsburg KS, Liang MH, Newcomer L, Goldhaber SZ, Schur PH, Hennekens CH: Anticardiolipin antibodies and the risk for ischemic stroke and thrombosis. Ann Int Med 1992;117:997-1002.

16 Schulman S, Svenungsson E, Granquist S, the Duration of Anticoagulation Study Group. Anticardiolipin antibodies predict early recurrence of thromboembolism and death among patients with venous thromboembolism following anticoagulant therapy. Am J Med 1998;104:332-338.

17 Carhuapoma JR Mitsias P, Levine SR: Cerebral venous thrombosis and anticardiolipin antibodies. Stroke 1997;28:2363-2369.

18 Gomez-Puerta JA; Martin H, Amigo MC, Aguirre MA, Camps MT, Cuadrado M, Hughes GR, Khamashta MA: Long-term follow-up in 128 patients with primary antiphospholipid syndrome: do they develop lupus? Medicine (Baltimore) 2005;84: 225-230.

19 Empson M, Lassere M, Craig J, Scott J: Recurrent pregnancy loss with antiphospholipid antibody: a systematic review of therapeutic trials. Obstet Gynecol 2002;99:135-144.
20 Mtiraouia N, Borgia L, Hizema S, Nsiria B, Finanb R, Gris JC, Almawi WT, Mahjouba W: Prevalence of antiphospholipid antibodies, factor V G1691A (Leiden) and prothrombin G20210A mutations in early and late recurrent pregnancy loss. Eur J Obstet Gynecol Reprod Biol 2005;119:164-170.

21 Rai RS, Clifford K, Cohen H, Regan L: High prospective fetal loss rate in untreated pregnancies of women with recurrent miscarriage and antiphospholipid antibodies. Hum Reprod 1995;10: 3301-3304.

22 Oshiro BT, Silver RM, Scott JR, Yu H, Branch DW: Antiphospholipid antibodies and fetal death. Obstet Gynecol 1996;87:489-493.

23 Bocciolone L, Meroni P, Parazrini F, Tincani A, Radici E, Tarantini M, Rossi E, Bianchi C, Mezzanotte C, D'Angelo A: Antiphospholipid antibodies and risk of intrauterine late fetal death. Acta Obstet Gynecol Scand 1994;73:389-392.

24 Robertson L, Wu O, Langhorne P, Twaddle S, Clark P, Lowe GDO, Walker ID, Greaves M, Brenkel I, Regan L, Greer I, for the Thrombosis: Risk and Economic Assessment of Thrombophilia Screening (TREATS) Study: Thrombophilia in pregnancy: a systematic review. Br J Haematol 2005;132: 171-196.

25 Dekker GA, de Vries JIP, Doelitzsch PM, Huijgens PC, von Blomberg BME, Jakobs C, van Geijn HP: Underlying disorders associated with severe earlyonset preeclampsia. Am J Obstet Gynecol 1995; 173:1042-1048

26 Kupferminc M: Thrombophilia and pregnancy. Reprod Biol Endocrinol 2003;1:111-163.

27 Yasuda M, Takakuwa K, Tokunaga A, Tanaka K: Prospective studies of the association between anticardiolipin antibody and outcome of pregnancy. Obstet Gynecol 1995;86:1-9.

28 Galli M: Pathogenesis of antiphospholipid syndrome. Thromb Res 2005;115(suppl 1)1:103-107.

29 Stalc M, Poredos P, Tomsic M, Sebestjen M, Kveder T: Endothelial function is impaired in patients with primary antiphospholipid syndrome. Thromb Res 2006;118:455-461.

30 Salafia CM, Cowchock FS: Placental pathology and antiphospholipid antibodies: a descriptive study. Am J Perinatol 1997;14:435-441.

31 Van Horn JT, Craven C, Ward K, Branch DW, Silver RM: Histologic features of placentas and abortion specimens from women with antiphospholipid and antiphospholipid-like syndromes. Placenta 2004:25:642-648

32 Rand J, Van Eerden P, Wu XX, Chazotte C: Defective annexin a5 crystallization: a mechanism for pregnancy losses in the antiphospholipid syndrome. Thromb Res 2005;115(suppl 1):77-81.

33 Sebire NJ, Fox H, Backos M, Rai R, Paterson C, Regan L: Defective endovascular trophoblast invasion in primary antiphospholipid antibody syndrome-associated early pregnancy failure. Hum Reprod 2002;17:1067-1071.

34 Bose P, Black S, Kadyrov M, Bartz C, Shlebak A, Regan L, Huppertz B: Adverse efects of lupus anticoagulant positive blood sera on placental viability can be prevented by heparin in vitro. Am J Obstet Gynecol 2004;192:23-30.

35 Quenby S, Mountfield S, Cartwright JE, Whitley G, Chamley L, Vince G: Antiphospholipid antibodies prevent extravillous trophoblast differentiation. Fertil Steril 2005;83:691-698.
36 Empson M, Lassere M, Craig J, Scott J: Prevention of recurrent miscarriage for women with antiphospholipid antibody or lupus anticoagulant. Cochrane Database Syst Rev 2005 Apr 18;(2):CD002859.

37 Ginsberg JS, Hirsh J: Use of antithrombotic agents during pregnancy. Chest 1998;114(suppl 5):524S$530 \mathrm{~S}$

38 Laskin CA, Bombardier C, Hannah ME, Mandel FP, Ritchie JWK, Farewell V: Prednisone and aspirin in women with autoantibodies and unexplained recurrent fetal loss. N Engl J Med 1997;337: 148-153.

39 Vaquero E, Lazzarin N, Valensise H, Menghini S, Di Pierro G, Cesa F, Romanini C: Pregnancy outcome in recurrent spontaneous abortion associated with antiphospholipid antibodies: a comparative study of intravenous immunoglobulin versus prednisone plus low-dose aspirin. Am J Reprod Immunol 2001;45:174-179.

40 Stephenson MD, Ballem PJ, Tsang P, Purkiss S, Ensworth S, Houlihan E, Ensom MH: Treatment of antiphospholipid antibody syndrome (APS) in pregnancy: a randomized pilot trial comparing low molecular weight heparin to unfractionated heparin. J Obstet Gynaecol Can 2004;26:729-734.

41 Noble LS, Kutteh WH, Lashey N, Franklin RD, Herrada J: Antiphospholipid antibodies associated with recurrent pregnancy loss: prospective, multicenter, controlled pilot study comparing treatment with low-molecular-weight heparin versus unfractionated heparin. Fertil Steril 2005;83:684-690.

42 Mecacci F, Mello G, Prisco D, Mignosa M, Ricci F, Cioni R, Scarselli G, Marchionni M, Paidas M: A comparative study of low dose aspirin and ether prophylactic dalteparin or unfractionated heparin in pregnancies complicated by antiphospolipid antibody syndrome. Eur J Obstet Gynecol Reprod Biol 2006;126:(in press).

43 Greer IA, Nelson-Piercy C: Low-molecular-weight heparins for thromboprophylaxis and treatment of venous thromboembolism in pregnancy: a systematic review of safety and efficacy. Blood 2005;106: 401-407.

44 Schleussner E, Westphal J, Seewald HJ: Pregnancy complications by antiphospholipid syndrome -5 years experiences of an university hospital. Thromb Res 2005;115(suppl 1):140-141.

45 Bauersachs RM, Dudenhausen J, Faridi A, Fischer T, Fung S, Geisen U, Harenberg J, Herchenhan E, Keller F, Kemkes-Matthes B, Schinzel H, Spannagl M, Thaler CJ: Safety and efficacy of low-molecular weight heparin in pregnant women at risk of venous thromboembolism: prospective cohort study. Thromb Res 2005;115(suppl 1):149.

46 Brenner B, Hoffman R, Carp H, Dulitsky M, Younis J, LIVE-ENOX Investigators: Efficacy and safety of two doses of enoxaparin in women with thrombophilia and recurrent pregnancy loss: the LIVE-ENOX study. J Thromb Haemost 2005;3: 227-229.

47 Smith MP, Norris LA, Steer PJ, Savidge GF, Bonnar J: Tinzaparin sodium for thrombosis treatment and prevention during pregnancy. Am J Obstet Gynecol 2004;190:495-501.

48 Bates SM, Greer IA, Hirsh J, Ginsberg JS: Use of antithrombotic agents during pregnancy: The Seventh ACCP Conference on Antithrombotic and Thrombolytic Therapy. Chest 2004;126;627-644. 